\title{
Legitimacy in REDD+ governance in Indonesia
}

\author{
${\text { Adelaide } \text { Glover }^{1} \cdot \text { Heike Schroeder }}^{1}$
}

Accepted: 19 December 2016/Published online: 7 January 2017

(C) The Author(s) 2017. This article is published with open access at Springerlink.com

\begin{abstract}
This paper addresses the question of legitimacy in REDD+ governance in Indonesia. It develops a legitimacy framework that builds on elements of Scharpf (J Eur Pub Policy 4(1):18-36, 1997) input and output legitimacy concept and the political economy lens described by Brockhaus and Angelsen (Analysing REDD+: Challenges and choices, CIFOR, Bogor, 2012). Using data collected through key informant interviews and focus groups, we identify and explore stakeholder perceptions of legitimacy. The analysis reveals a complex interplay between input and output legitimacy, finding that state, nonstate and hybrid actors perceive output legitimacy (i.e. project outcomes) as highly dependent on the level of input legitimacy achieved during the governance process. Nonstate actors perceive proxies for input legitimacy, such as participation and inclusion of local people, as goals in themselves. In the main, they perceive inclusion to be integral to the empowerment of local people. They perceive output legitimacy as less important because of the intangibility of REDD+ outcomes at this stage in the process. The findings also highlight the challenges associated with measuring the legitimacy of REDD+ governance in Indonesia.
\end{abstract}

Keywords Legitimacy - REDD+ · Governance · Non-state actors · Political economy · Indonesia

$\begin{array}{ll}\text { Abbreviations } \\ \text { COP } & \text { Conference of the Parties } \\ \text { GHG } & \text { Greenhouse Gas } \\ \text { LoI } & \text { Letter of Intent } \\ \text { MoU } & \text { Memorandum of Understanding } \\ \text { NGO } & \text { Non-governmental Organisation }\end{array}$

Adelaide Glover

adelaide.glover@gmail.com

1 School of International Development, University of East Anglia, Norwich NR4 7TJ, UK 
REDD+ Reducing emissions from deforestation and forest degradation in developing countries, and the role of conservation, sustainable management of forests, and enhancement of forest carbon stocks in developing countries

UN United Nations

UNFCCC United Nations Framework Convention on Climate Change

\section{Introduction}

REDD+ is an international forestry mechanism under the United Nations Framework Convention on Climate Change (UNFCCC). It is designed to incentivise reductions in greenhouse gas (GHG) emissions by reducing deforestation and forest degradation, conserving and enhancing forest carbon stocks and sustainably managing forests. The Bali Action Plan, adopted at the thirteenth Conference of the Parties (COP-13), encourages all Parties to the UNFCCC to support developing countries through capacity building and improving the institutional setting to reduce emissions from deforestation and forest degradation (UNFCCC 2007).

Much research into the governance of REDD+ (e.g. Corbera and Schroeder 2011; Thompson et al. 2011; Visseren-Hamakers et al. 2012a) approaches governance performance from a results rather than a legitimacy point of view (Rosendal and Andresen 2011). This study explores REDD+ governance through a legitimacy lens. It examines how legitimacy is contested, how it is perceived by state, non-state and hybrid actors and what concepts are used to describe and assess it.

Indonesia is the focus of this study because of its multiple stakeholders and interests involved in REDD+ governance, allowing for analysis of a range of perceptions of legitimacy. The country's broader context makes it a relevant case study too; it is the second highest emitter of $\mathrm{CO}_{2}$-equivalent from land use, land use change and forestry (FAO 2010), it receives substantial financial support from Norway to develop REDD+ (Edwards et al. 2012) and has a complex political economy as a result of decentralization and the numerous ministries governing land use (Indrarto et al. 2012; Di Gregorio et al. 2012; Luttrell et al. 2014; Mulyani and Jepson 2013).

The paper proceeds as follows. It first offers a brief introduction of REDD+ in Indonesia and explores current propositions on legitimacy. It then explains input and output legitimacy and tests a set of propositions with key informant and focus group data. The findings are then discussed in light of how different stakeholders perceive legitimacy and the challenges of assessing legitimacy in the context of REDD+.

\section{REDD+ governance in Indonesia}

Following the Bali Action Plan adopted at COP-13, diverse partnerships between developed and developing countries, non-governmental organisations (NGOs), the United Nations (UN) and the World Bank were established to implement REDD+. One partnership is the Letter of Intent (LoI) between the Government of Norway and the Government of Indonesia in which Norway pledges US\$ one billion to reduce emissions from deforestation and forest degradation in Indonesia (Government of Indonesia and Government of Norway 2010). 
In response to the LoI, the President of Indonesia established a REDD+ Task Force under Presidential decree (Government of Indonesia 2011). The Task Force, represented by the Ministries of Finance, Agriculture, Forestry, Energy and Mineral Resources, the National Land Agency and the Cabinet Secretariat, what was later merged with the REDD+ Transition Team to form the REDD+ Management Agency, is mandated to coordinate the National REDD+ Strategy (SATGAS 2012; Government of Indonesia 2011). This indicates that REDD+ in Indonesia has become an issue of broader land use governance. This could present a challenge on the basis that coordination between some of these institutions, such as the Ministry of Agriculture, the Land Agency and the Ministry of Forestry, has historically been problematic (Atmadja and Wollenberg 2010; Edwards et al. 2012).

An array of different interests, ideas, institutions and information characterise the complex political economy surrounding REDD+ (Brockhaus and Angelsen 2012). The most significant aspect of the political economy in Indonesia is the dual commitment to seven per cent economic growth (UKP4 2013) and 26-41\% GHG emission reductions (Bappenas 2010), also known as 'Target 7/26' (UKP4 2013).

Forests will play a role in meeting both these targets, as much of Indonesia's tax revenues come from the forest sector (Indrarto et al. 2012) and through REDD+ forests will play a vital role in reducing national GHG emissions. Luttrell et al. (2014) propose that those countries holding the highest potential to reducing emissions from tropical deforestation tend also to be subject to complex democratisation and decentralisation conditions with a complex political economy surrounding the forest sector. Decentralisation within Indonesia has led to extensive forest degradation, with autonomy given to provincial and district governments. Permits have been issued by them illegitimately as a result of disjointed spatial information (Indrarto et al. 2012).

\section{Legitimacy in the complex landscape of REDD+ governance}

\subsection{Assessing legitimacy}

The political economy surrounding REDD+ in Indonesia influences different actors' perceptions of legitimacy. Interests, ideas, information and institutions influence the motivations for gaining and maintaining legitimacy as well as the values placed upon each type of legitimacy. Below we examine the subjective nature of legitimacy through different stakeholders' perceptions of it.

\subsubsection{Input and output legitimacy}

As described by Scholte, 'legitimacy prevails when authority has the consent of those who are subject to it' (2011:111). This consent can be achieved in a normative sense such as through the command of a democratically elected leader or it can be achieved in a sociological sense, for instance when an NGO gains the trust of a community through local participation and evidence that decisions made by them are effective (Buchanan and Keohane 2006). The differentiation between input and output legitimacy (Scharpf 1997) helps to assess how different actors gain and maintain legitimacy in a governance regime.

Input legitimacy can come in the form of balanced representation of stakeholder networks, accountability and transparency mechanisms (Bäckstrand 2006). Input legitimacy 
exists when stakeholders are involved in the decision-making process (Lederer 2011). This research uses the proxy of inclusion and participation of local people in decision-making processes to measure the performance of input legitimacy.

Output legitimacy is the acceptance of certain rules because of their ability to solve problems, which relates to effectiveness (Biermann and Gupta 2011). It is important to note, however, that in some cases this acceptance may be short-lived if the 'rules' are deemed effective initially but fail to meet long-term goals. This research uses the proxy of positive project outcomes to evaluate the performance of output legitimacy.

In order to assess the output legitimacy of REDD+ an understanding of the mechanism's objectives is required. Since its inception, what is known as REDD+ today has the addition of many more objectives, and these vary depending on specific national REDD+ strategies.

National REDD+ initiatives are made up of numerous policies and measures, which are based on a variety of goals and objectives. They include the multiple objectives of REDD+ itself (reducing emissions from deforestation and degradation as well as conservation, sustainable management of forests and enhancement of forest carbon stocks) but also a number of social and environmental objectives captured in the REDD+ safeguards, which are closely aligned with existing national forest programmes (McDermott et al. 2012; Visseren-Hamakers et al. 2012b). The UNFCCC safeguards (UNFCCC 2011) include the following:

1. Consistency with national forests programmes and international agreements (policy coherence).

2. Transparent and effective governance structures.

3. Respects for knowledge and rights of indigenous peoples and local communities.

4. Full and effective participation of relevant stakeholders.

5. Consistency with conservation of biodiversity and ensuring against conversion of natural forests.

6. Addressing risk of reversals (ensuring permanence).

7. Reducing displacement.

Such a broad set of goals and objectives presents a challenge for gaining and maintaining legitimacy because each stakeholder has different expectations for REDD+.

The Cancún Agreements state that REDD+ safeguards 'should be promoted and supported' by national REDD+ strategies (UNFCCC 2011:26). This rather weak language means that governments are not legally required to implement the safeguards in achieving REDD+ objectives, which may lead to a neglect of input legitimacy-in the form of full and effective participation of relevant stakeholders. Lederer (2011) suggests that REDD+ will not save Indonesia's forests alone, and that attempting to do this while simultaneously preserving biodiversity and local people's livelihoods is an immense task, which will inevitably lead to trade-offs and unintended consequences such as community conflicts and loss of livelihoods. To avoid these unintended consequences, the legitimacy of REDD+ governance needs to be ensured.

\subsubsection{Legitimacy in the eyes of whom?}

Legitimacy entails that those communities accept the organisation as appropriately engaged in the task at hand. (Bernstein 2011: 24) 
Assessing the legitimacy of organisations requires an understanding of which communities are affected and who is being governed by whom (Biermann and Gupta 2011; Scholte 2011). More to the point, in order to assess legitimacy, a critical question that needs to be asked is 'legitimacy in the eyes of whom?' (Biermann and Gupta 2011:1858).

The ability of an institution to perform governance functions may depend on whether those whom the governance function addresses regard them as legitimate (Buchanan and Keohane 2006). Inclusion of a range of stakeholders in a governance regime is thought to contribute to securing greater accountability and legitimacy (Biermann and Gupta 2011), but identifying who these stakeholders are is a difficult task (Risse 2006). Stakeholders involved in REDD+ governance in Indonesia include local communities, local farmers, small-, medium- and large-sized national and multinational companies, local, national and international NGOs and district, provincial and national governments.

An organisation may diverge dramatically from societal norms yet retain legitimacy because the divergence goes unnoticed (Suchman 1995). This may be the case if an organisation is delivering results (output legitimacy) but via socially 'illegitimate' means. Brockhaus et al. (2012) make the recommendation of outlining a clear and uncontested definition of who has the authority to make decisions about land use, but with so many interests and stakeholders governing land and forests in Indonesia this is no easy task. Legal clarity is required as well as a clear understanding of which institutions have the right to make decisions on REDD+ activities (Luttrell et al. 2014). Coordination of actors involved in this process is clearly a difficult task given the fragmentation between national and subnational government and the multiple interests involved in REDD+ in Indonesia (Luttrell et al. 2014; Brockhaus et al. 2012).

\section{Methodology}

Our methodology consists of two stages, data collection and data analysis.

\subsection{Data collection}

Fieldwork was undertaken in various locations throughout Indonesia during May and June of 2013. Interviews were conducted at the national level in the capital city of Jakarta, at the provincial level in Palangka Raya, Central Kalimantan and at the district level in Berau, East Kalimantan. The provincial and district level locations were selected on the basis of their progress with REDD+ and accessibility. In addition, three focus group discussions and participant observations were carried out at a conference on the socialisation of the Provincial REDD+ Strategy in Pangkalanbun and at two REDD+ project sites in East and Central Kalimantan.

\subsubsection{Sampling}

A non-probability sampling method was employed in this research. Participants were selected based on their level of knowledge and involvement (Patton 2002) in REDD+ from the national level to the provincial and district levels. Brockhaus et al. (2012) outline ten main institutional players in the REDD+ policy arena in Indonesia. Through strategic sampling, participants from five of these key institutions were interviewed. Participants 
Table 1 Classification of research participants

Total $n=24$

\begin{tabular}{llll}
\hline Interviews $(n=21)$ & State & Non-state & Hybrid \\
\hline National & 4 & 4 & 1 \\
Provincial/district & 4 & 7 & 1 \\
Focus groups $(n=3)$ & State & Non-state & Hybrid \\
National & 0 & 0 & 1 \\
Provincial/district & 0 & 1 & 1 \\
\hline
\end{tabular}

were also selected using convenience and snowball sampling. Table 1 presents the sample of participants according to their classification.

Participants were classified into the six categories in Table 1. State actors at the national, provincial and district levels are from government agencies engaged in REDD+. Non-state actors at the three levels include domestic and international NGOs, the private sector and academics. Hybrid actors are collaborations between state and non-state actors. This classification ensures the anonymity of the participants and allows for comparisons to be drawn between the actors.

\subsubsection{Semi-structured interviews}

The primary method of data collection was semi-structured key informant interviews. Interviews were recorded where possible (18/21); otherwise, notes were taken. An interview guide consisting of a combination of closed and open-ended questions was used to guide the interview.

\subsubsection{Focus group discussions}

Three focus groups were held, one with hybrid actors at the Ministry of Forestry in Jakarta, one with hybrid actors at the district forest management unit in Berau and one with a local community in Berau district. These discussions were to allow members of a group to bring forward their ideas and concerns about REDD+.

\subsection{Data analysis}

A literature review was carried out to assess and evaluate the existing work on legitimacy and REDD+ in Indonesia. The literature review helped with identifying a suitable framework to analyse the data. Interview scripts were transcribed and field notes were synthesised to allow for analysis. In order to produce a set of themes from the data collected, data was coded, which allowed for comparison and subsequent quantitative analyses to be made (Corbetta 2003). The coding process produced over twenty themes, which were tabulated and their frequency within interview transcripts and field notes was recorded. The themes produced from coding were also analysed in relation to the research topic, which allowed for the most relevant themes to be highlighted (Bryman 2012). Each participant's perception of legitimacy in REDD+ governance was then framed into three categories that represent the most frequently mentioned perspectives on legitimacy. These perceptions were tabulated and each actor category citing this perception was recorded. This allows for comparisons to be made about state, non-state and hybrid actors and their perceptions of legitimacy in REDD+ governance. 


\section{Perceptions of legitimacy in REDD+ governance in Indonesia}

Three dominant perceptions surrounding the legitimacy of REDD+ governance in Indonesia were identified. They draw a complex picture of legitimacy.

\subsection{Input legitimacy is key to REDD+}

This research finds that input legitimacy, established through inclusion and participation of local people, is vital to the governance of REDD+ in Indonesia. This was cited by all actor categories, and the majority of key informants and focus groups (22/24) which indicates its high importance in REDD+ governance. Key informants described input legitimacy as a prerequisite for projects, 'well like the inclusion is given like all projects have to do it whether you like it or not' (Provincial/District Non-state Actor 3).

Another key informant highlighted that input legitimacy is employed for pragmatic reasons. Without local people's participation and understanding the project will not work; 'my point is REDD is something on the ground, so if you're not touching the ground you've got nothing. So if you come to the ground and meet people who don't understand you've got nothing, we have to make them aware and make them have willingness to participate' (National State Actor 1).

One exception of this view is illustrated by one key informant suggesting that the community they engaged with were not involved in a consultative process but agreed to go ahead because of the outcomes of the project (output legitimacy), 'actually, they do not really know about the project, even though we have already said to them. There is darkness around REDD+. For this time they give their consent, because they can see the benefit' (Provincial/District Non-state Actor 5). This attitude towards REDD+ may be because the socialisation of REDD+ at the provincial and district levels was in its early stages. This perception suggests that, in some cases, output legitimacy is considered to be important to some communities. However, Steffek (2003) highlights that output legitimacy refers to the material benefits provided by a system, and although these are enjoyed by the governed, this provision is not enough to grant an actor legitimacy. The majority of participants suggest that it is still important to ensure the methods, such as full and effective participation of local people (input legitimacy), used to reach these material benefits are considered legitimate by the governed.

Furthermore, it is important to identify the extent or quality of each type of legitimacy to ensure that legitimacy can be genuinely granted by stakeholders. For instance, the proxy used for input legitimacy is inclusion and participation of local people; however, this inclusion cannot be taken at face value. This was evident at a conference on the socialisation of the Provincial REDD+ Strategy in Central Kalimantan where, although there were plenty of opportunities for stakeholders to express their views, the agenda set by the event organisers, the provincial government and Satgas REDD+, meant that some of the concerns of local farmers were excluded. In this particular case, the local farmers were interested to learn more about large-scale palm oil companies in the area and the implications for REDD+, but this topic was not discussed further because of the agenda and time constraints. So, although output legitimacy is achieved in the eyes of the conference organisers, input legitimacy, in the eyes of the local farmers, was undermined, showing the trade-off between the two.

The research has also highlighted some important considerations around what constitutes output legitimacy. Though described here as positive project outcomes, these 
outcomes can come in various forms and can be valued differently by different actors. The most highly cited (23/24) positive project outcome was livelihood improvements: 'in the end most communities first and foremost are only interested in protecting their livelihoods they're interested in making sure they have an income making sure they have fish and you know rattan and in the end I think many communities don't really have a preference of who's meant to provide that as long as somebody does...' (National Non-state Actor 1). In other words, participants consider output legitimacy to be achieved if livelihoods are improved first and foremost. However, this presents a challenge considering that the objectives of REDD+, discussed earlier, go beyond livelihood improvements. As discussed earlier, the primary objective of REDD+ is to reduce emissions and conserve forests, and so some actors would measure output legitimacy based on these variables and not on the provision of livelihood improvements.

Alongside this recognition for output legitimacy, input legitimacy is also valued strongly: 'they're just happy to get support from anywhere...one of the villages I know there are many actors working there but the head of the village is pretty clear on what the community want' (Provincial/District Non-state Actor 3). This quote highlights that communities do not have a preference as to who provides REDD+ assistance, as long as there is input legitimacy, in the form of inclusion in the process through meaningful consideration of their needs, and as long as output legitimacy is produced in the form of livelihood improvements.

Does this mean then, that one cannot have output legitimacy without input legitimacy? Participants (19/24) from all actor categories except National were of the view that input and output legitimacy cannot be mutually exclusive; 'You can't see those things as mutually exclusive, so for you to have successful long-term project outcomes there has to be ownership of the project at the community level' (National Non-state Actor 2).

In this case, REDD+ will not have positive project outcomes if local people are excluded from participating in projects, 'for REDD+ to be successful community involvement has to be embedded within it' (National State Actor 3). This is consistent with initial findings from the KFCP project in Central Kalimantan. The project was criticised for having low input legitimacy by excluding local people, as well as low output legitimacy by missing emission reduction targets (Forest Peoples Programme 2012; Howson 2013). However, a more recent assessment of the KFCP project finds that the initial controversy was unfounded. Atmadja et al. (2014) surveyed a broader set of community members and found that a majority received some livelihoods benefits from the project and many wanted it to continue.

The relationship between input and output legitimacy will always depend on the stakeholders involved. Returning to the question, 'legitimacy in the eyes of whom?', it is clear that in some cases the relationship is not that straightforward. For example, Wong et al. (2016) highlight the importance of broad-based consultation in development projects. Eliciting the views of only a select few, as was the case with the villages surrounding the Bukit Baka-Bukit Raya National Park in West Kalimantan, can mean that the majority of the population can deem a project illegitimate, despite approval from village heads.

\subsection{Input legitimacy serves as a goal in itself}

This research finds that only non-state actors see input legitimacy as a goal in itself; inclusion of all stakeholders can be a project goal or used as proxies for output legitimacy, 'social inclusion is part of the target of the outcome' (Provincial/District Non-state Actor 4). This indicates that they see inclusion and participation of local people as so 
instrumental to the success of projects that it is considered an outcome in itself, 'but if somehow you manage to keep them involved in the whole process I mean that's one of the successes' (Provincial/District Non-state Actor 3). Understanding why non-state actors have this perspective, while state and hybrid actors do not, requires an analysis of the interests, ideas, institutions and information surrounding them.

The perception of non-state actors that proxies for input legitimacy can serve as goals in themselves may stem from the fact that effective participation is included in the safeguarding of REDD+. Furthermore, non-state actors are seen to contribute to empowering marginalised actors in governance processes as well as in monitoring government compliance of international agreements (Bäckstrand 2013). This is reflected in our findings, as non-state actors value inclusion in recognition of the UNFCCC safeguards.

One exception of this view was expressed by one key informant who suggested that the community they engaged with were more concerned about output legitimacy, 'actually, they do not really know about the project, even though we have already said to them. There is darkness around REDD+. For this time they give their consent, because they can see the benefit' (Provincial/District Non-state Actor 5). This attitude towards REDD+ may be because the socialisation of REDD+ at the provincial and district level is its early stages. This perception suggests that in some cases, output legitimacy is considered to be more important to some communities. However, Steffek (2003) highlights that output legitimacy refers to the material benefits provided by a system and although these are enjoyed by the governed, this provision is not enough to grant an actor legitimacy.

State and hybrid actors, on the other hand, do not necessarily see input legitimacy or inclusion as a goal in itself, but they do recognise that it is key to achieving the overarching goal of REDD+: 'my point is REDD is something on the ground, so if you're not touching the ground you've got nothing. So if you come to the ground and meet people who don't understand you've got nothing, we have to make them aware and make them have willingness to participate' (National State Actor 1).

As state actors, in the context of REDD+, they are mandated by their institutions, e.g. the MoU between Indonesia and Norway, to implement emissions reductions, as well as by their economic interests to meet emissions reduction targets to receive REDD+ finance. State actors are also accountable to the communities they serve, and therefore should recognise the importance of community participation. However, as this is not the primary goal of REDD+, this perception did not resonate among state actors, 'our common goal is how to increase the production and to decrease the emission' (National State Actor 1).

\subsection{Motives for maintaining legitimacy depend on stakeholders' interests and ideas}

Different stakeholders have varying motives for maintaining legitimacy depending on their interests and ideas. This research finds that state actors maintain input legitimacy for political reasons as it is in their mandate to protect communities: 'the government...I mean they also have an interest in protecting communities...communities vote' (National Nonstate Actor 1).

International NGOs (non-state actors) maintain their legitimacy to the local communities involved in REDD+ projects through working closely with the national government in Indonesia (Galudra et al. 2010); their motivation for maintaining legitimacy is based on their own ideas and interests, which, with regards to REDD+ are focused on non-carbon benefits (Angelsen et al. 2008). There is also pressure from international and national institutions for non-state actors to focus on these non-carbon benefits (Angelsen et al. 
2008). This may offer some explanation as to why non-state actors value input legitimacy so highly, as the empowerment of local people resulting from their inclusion can be considered as one of the non-carbon benefits of REDD+. The fact that many non-state actors working in the forest sector in Indonesia focus on rights-based development due to the country's history of community conflicts may offer another explanation for this perception. This analysis highlights that an actor's interest, be it political, social, environmental or economic, influences their motivation to maintain legitimacy.

However, the broader political economy, characterised by the numerous actors involved, poor coordination between ministries and limited forest management capacity, has the potential to undermine input legitimacy and the effectiveness of participation in REDD+ governance in Indonesia. Ensuring that the interests of all stakeholders are effectively participating in the process is no easy task as highlighted by Cadman and Maraseni (2013) who found that in Nepal, despite the REDD+ governance process being considered inclusive by both state and non-state actors, there were not enough resources or capacity to produce meaningful participation. Also, in Peru it was found that REDD+ project developers, intermediaries and forest users are poorly coordinated (Zelli et al. 2014). These examples suggest that input legitimacy was present, but output legitimacy could not be achieved due to a lack of capacity.

One non-state actor highlighted that the level and extent of inclusion within REDD+ goes beyond that of local people, 'if REDD come to our territory you must inform our spirit not only the human' (Provincial/District Non-state Actor 1). How project developers and policy makers go about including this intrinsic spiritual value of forests into REDD+ project design is a question is beyond the scope of this research. It highlights the challenge of achieving input legitimacy in settings that involve stakeholders with such a diverse range of cultural and spiritual values, which are usually neither understood nor taken seriously on the part of project developers.

\section{Discussion: The challenges of assessing legitimacy}

This research finds that input legitimacy is extremely important to the success of REDD+. However, there is a need to understand the extent to which inclusion and participation are effective and meaningful. The issues of coordination and capacity in forest governance in Indonesia discussed earlier have the potential to undermine the extent to which input legitimacy is meaningful and effective participation.

There is an immense literature surrounding participation in environmental governance, which raises questions about the quality and breadth of participation by local people. Often exclusion can occur during inclusionary processes; at the Provincial REDD+ Strategy socialisation conference the prescribed topics on the agenda and time limitations meant that the concerns of some local farmers were excluded. This is known as procedural exclusion (Peterson 2011), and highlights that even though organisers perceived the process to be inclusionary; in reality the real concerns of participants were ignored.

Another challenge of assessing legitimacy is related to the output side. As highlighted in the analysis, the carbon, environmental and social objectives encompassed in REDD+ make assessing output legitimacy difficult, inevitably leading to trade-offs between the objectives. Furthermore, the high number of actors involved in REDD+ makes identifying common priorities difficult (Visseren-Hamakers et al. 2012a). 
The long-term nature of environmental governance projects such as REDD+ also means that the outcomes cannot be immediately evaluated, adding to the complexity of assessing output legitimacy. Though output legitimacy concerns the effectiveness of governance, achieving output legitimacy also relies on the perceptions of effectiveness by stakeholders, meaning that resolving the underlying problem may not necessarily occur (Biermann and Gupta 2011).

A stakeholder's perception of legitimacy is influenced by their individual interests and ideas. For instance, if a governance arrangement set out to reduce emissions and failed to do so, but in the process provided a community with livelihoods, this community may grant those governing the project legitimacy even though they are not achieving the project's original goal. In this case, the community's primary interest is in improving their livelihoods, but if the other objectives of REDD+ are not met, such as carbon reductions, then the project may be deemed illegitimate by those who have a greater interest in climate change mitigation. This is problematic because in such cases funding and resources may be taken away, leaving the communities disenfranchised with the project, which may lead to a lack of community interest in future projects.

Furthermore, as different actors desire varied outcomes for REDD+, assessing output legitimacy in the future will remain a difficult task. These issues are echoed in the research findings, and explain the greater emphasis on input legitimacy within REDD+ governance.

This research highlights that non-state actors see input legitimacy as so instrumental to the success of REDD+ that they consider it as a goal in itself. Perceptions of legitimacy vary depending on each actor's context. For example, the suggestion that the world of spirit should be part of the local REDD+ decision-making process may not be deemed necessary by some but vital to indigenous peoples who have a connection to the forest beyond its economic value (Wadley and Colfer 2004). This point follows on from the discussion about the quality and extent of participation of the numerous stakeholder groups involved in REDD+ governance.

\section{Conclusion}

This research finds that there is a complex relationship between input and output legitimacy and this affects the success of REDD+ governance. The importance of input legitimacy to non-state actors is evident in the fact that they perceive proxies for input legitimacy as goals in themselves. In addition, the extent to which input legitimacy influences output legitimacy depends on the individual perceptions of the various stakeholders involved. We do find though that many stakeholders are of the view that input and output legitimacy cannot be mutually exclusive. This reinforces the importance of inclusion and participation of local people in REDD+ governance.

Output legitimacy is deemed to be of less importance to non-state actors, due to the intangibility of the outcomes of REDD+ at such an early stage in the process. Furthermore, there are constraints to assessing output legitimacy because of the range of objectives included under the REDD+ mechanism, which vary depending on the actors involved.

The varying objectives of REDD+ and the different values placed upon them by the various stakeholders involved are influenced by their interests and ideas as well as the political economy at the project and policy level. These objectives affect stakeholder perceptions of legitimacy and the values they place on input and output legitimacy. 
This research also highlights the challenges of assessing legitimacy, which can help to inform future research into the governance quality of REDD+ and other global environmental governance mechanisms. The proxies used to categorise legitimacy in this research are subject to individual perceptions of input and output legitimacy and the values placed upon them. Diverging perceptions of what constitutes effective participation and positive project outcomes requires a thorough assessment of the stakeholders involved in, and the input and output legitimacy of, REDD+ governance in Indonesia.

Open Access This article is distributed under the terms of the Creative Commons Attribution 4.0 International License (http://creativecommons.org/licenses/by/4.0/), which permits unrestricted use, distribution, and reproduction in any medium, provided you give appropriate credit to the original author(s) and the source, provide a link to the Creative Commons license, and indicate if changes were made.

\section{References}

Angelsen, A., Streck, C., Peskett, L., Brown, J., \& Luttrell, C. (2008). What is the right scale for REDD. In A. Angelsen (Ed.), Moving ahead with REDD: issues, options and implications (pp. 31-40). CIFOR: Bogor.

Atmadja, S., Indriatmoko, Y., Utomo, N. A., Komalasari, M., \& Ekaputri, A. D. (2014). Kalimantan forests and climate partnership, Central Kalimantan, Indonesia. In E. O. Sills, S. Atmadja, C. Sassi, A. E. de Duchelle, D. Kweka, I. A. P. Resosudarmo, \& W. D. Sunderlin (Eds.), REDD+ on the ground: A case book of subnational initiatives across the globe (pp. 290-308). Bogor: CIFOR.

Atmadja, S., \& Wollenberg, E. (2010). Indonesia. In O. Springate-Baginski \& E. Wollenberg (Eds.), REDD, forest governance and rural livelihoods: The emerging agenda (pp. 73-94). Bogor: CIFOR.

Bäckstrand, K. (2006). Multi-stakeholder partnerships for sustainable development: Rethinking legitimacy, accountability and effectiveness. European Environment, 16(5), 290-306.

Bäckstrand, K. (2013). The democratic legitimacy and legitimation of global climate governance. Paper presented at the Earth System Governance Conference, Tokyo, 28-31 January 2013.

Bappenas. (2010). Indonesia climate change sectoral roadmap: Forestry. http://www.bappenas.go.id/getfile-server/node/10612/. Accessed July 12, 2013.

Biermann, F., \& Gupta, A. (2011). Accountability and legitimacy in earth system governance: A research framework. Ecological Economics, 70(11), 1856-1864.

Brockhaus, M., \& Angelsen, A. (2012). Seeing REDD+ through 4Is: A political economy framework. In A. Angelsen, M. Brockhaus, W. D. Sunderlin, \& L. V. Verchot (Eds.), Analysing REDD+: Challenges and choices (pp. 15-30). Bogor: CIFOR.

Brockhaus, M., Obidzinski, K., Dermawan, A., Laumonier, Y., \& Luttrell, C. (2012). An overview of forest and land allocation policies in Indonesia: Is the current framework sufficient to meet the needs of REDD+? Forest Policy and Economics, 18, 30-37.

Bryman, A. (2012). Social research methods (4th ed.). New York: Oxford University Press.

Buchanan, A., \& Keohane, R. O. (2006). The legitimacy of global governance institutions. Ethics \& International Affairs, 20(4), 405-437.

Cadman, T., \& Maraseni, T. (2013). More equal than others? A comparative analysis of state and non-state perceptions of interest representation and decision-making in REDD+ negotiations. Innovation: The European Journal of Social Science Research, 26(3), 214-230.

Corbera, E., \& Schroeder, H. (2011). Governing and implementing REDD+. Environmental Science \& Policy, 14(2), 89-99.

Corbetta, P. (2003). Social research: Theory, methods and techniques. London: Sage.

Di Gregorio, M., Brockhaus, M., Cronin, T., \& Muharrom, E. (2012). Politics and power in national REDD+ policy processes. In A. Angelsen, M. Brockhaus, W. D. Sunderlin, \& L. V. Verchot (Eds.), Analysing REDD+: Challenges and choices (pp. 69-90). Bogor: CIFOR.

Edwards, D. P., Koh, L. P., \& Laurance, W. F. (2012). Indonesia's REDD+ pact: Saving imperilled forests or business as usual? Biological Conservation, 151(1), 41-44.

FAO. (2010). National net emissions removals from net forest conversion. http://faostat3.fao.org/home/ index.html\#DOWNLOAD. Accessed August 5, 2013.

Forest Peoples Programme. (2012). Unfulfilled promises: A note on the KFCP's recent attempts to respect the rights of affected communities on the Kapuas River, Central Kalimantan. http://www.forestpeoples. 
org/sites/fpp/files/publication/2012/09/kfcp-commitments-after-year-promises-final.pdf. August 3, 2013.

Galudra, G., van Noordwijk, M., Sunyato, I. S., \& Pradhan, U. (2010). Hot spot of emission and confusion: Land tenure insecurity, contested policies and competing claims in the Central Kalimantan ex-mega rice project area. Working paper 98. Bogor: World Agroforestry Centre.

Government of Indonesia. (2011). Article 5: The REDD+ agency task force membership structure. http:// sipuu.setkab.go.id/PUUdoc/17271/Keppres0252011.pdf. Accessed July 12, 2013.

Government of Indonesia and Government of Norway. (2010). Letter of intent between the Government of the Kingdom of Norway and the Government of the Republic of Indonesia on 'Cooperation on reducing greenhouse gas emissions from deforestation and forest degradation'. http://www.norway.or.id/ PageFiles/404362/Letter_of_Intent_Norway_Indonesia_26_May_2010.pdf. Accessed July 31, 2013.

Howson, P. (2013). Over the REDD rainbow. The Jakarta Post. 15 August. http://www.thejakartapost.com/ news/2013/08/15/over-redd-rainbow.html. Accessed August 17, 2013.

Indrarto, G. B., Murharjanti, P., Khatarina, J., Pulungan, I., Ivalerina \& F., Rahman, J. (2012). The context of REDD+ in Indonesia: Drivers, agents and institutions. Working paper 92. Bogor: CIFOR.

Lederer, M. (2011). From CDM to REDD+-What do we know for setting up effective and legitimate carbon governance? Ecological Economics, 70(11), 1900-1907.

Luttrell, C., Resosudarmo, I. A. P., Muharrom, E., Brockhaus, M., \& Seymour, F. (2014). The political context of REDD+ in Indonesia: Constituencies for change. Environmental Science \& Policy, 35, $67-75$.

McDermott, C. L., Coad, L., Ariella Helfgott, A., \& Schroeder, H. (2012). Operationalizing social safeguards in REDD+: Actors, interests and ideas. Environmental Science \& Policy, 21, 63-72.

Mulyani, M., \& Jepson, P. (2013). REDD+ and forest governance in Indonesia: A multi-stakeholder study of perceived challenges and opportunities. The Journal of Environment Development, 22(2), 1-23.

Patton, M. Q. (2002). Qualitative research and evaluation methods. Thousand Oaks: Sage.

Peterson, N. D. (2011). Excluding to include: (Non) Participation in Mexican natural resource management. Agriculture and Human Values, 28(1), 99-107.

Risse, T. (2006). Transnational governance and legitimacy. In A. Benz \& I. Papadopoulos (Eds.), Governance and democracy: Comparing national, European and international experiences (pp. 179-199). New York: Routledge.

Rosendal, G. K., \& Andresen, S. (2011). Institutional design for improved forest governance through REDD: Lessons from the global environment facility. Ecological Economics, 70(11), 1908-1915.

SATGAS. (2012). REDD+ national strategy. Jakarta: Indonesian National REDD+ Task Force.

Scharpf, F. W. (1997). Economic integration, democracy and the welfare state. Journal of European Public Policy, 4(1), 18-36.

Scholte, J. A. (2011). Towards greater legitimacy in global governance. Review of International Political Economy, 18(1), 110-120.

Steffek, J. (2003). The legitimation of international governance: A discourse approach. European Journal of International Relations, 9(2), 249-275.

Suchman, M. C. (1995). Managing legitimacy: Strategic and institutional approaches. Academy of Management Review, 20(3), 571-610.

Thompson, M. C., Baruah, M., \& Carr, E. R. (2011). Seeing REDD+ as a project of environmental governance. Environmental Science \& Policy, 14(2), 100-110.

UKP4. (2013). Partnering the new paradigm: Sustainable development. http://www.ukp.go.id/siaran-pers/ 121-bermitra-dalam-paradigma-baru-pembangunan-berkelanjutan. Accessed July 11, 2013.

UNFCCC. (2007). Decision 2/CP.13 Reducing emissions from deforestation in developing countries: Approaches to stimulate action. Report of the Conference of the Parties on its thirteenth session, held in Bali from 3 to 15 December 2007. http://unfccc.int/resource/docs/2007/cop13/eng/06a01.pdf. Accessed July 12, 2013.

UNFCCC. (2011). Decision 1/CP.16. The Cancun agreements: Outcome of the work of the Ad Hoc Working Group on Long-term Cooperative Action under the Convention Report of the Conference of the Parties on its sixteenth session, held in Cancun from 29 November to 10 December 2010. http://unfccc.int/ resource/docs/2010/cop16/eng/07a01.pdf. Accessed July 10, 2013.

Visseren-Hamakers, I. J., Gupta, A., Herold, M., Peña-Claros, M., \& Vijge, M. J. (2012a). Will REDD+ work? The need for interdisciplinary research to address key challenges. Current Opinion in Environmental Sustainability, 4(6), 590-596.

Visseren-Hamakers, I. J., McDermott, C., Vijge, M. J., \& Cashore, B. (2012b). Trade-offs, co-benefits and safeguards: Current debates on the breadth of REDD+. Current Opinion in Environmental Sustainability, 4(6), 646-653. 
Wadley, R. L., \& Colfer, C. J. P. (2004). Sacred forest, hunting, and conservation in West Kalimantan, Indonesia. Human Ecology, 32(3), 313-338.

Wong, G., Brockhaus, M., Moeliono, M., Padoch, C., \& Pham, T. T. (2016). Equity, REDD+ and benefit sharing in social forestry (No. CIFOR Infobrief No. 142). Bogor: Center for International Forestry Research (CIFOR).

Zelli, F., Erler, D., Frank, S., Hein, J. I., Hotz, H., \& Santa Cruz Melgarejo, A. M. (2014). Reducing emissions from deforestation and forest degradation (REDD) in Peru: A challenge to social inclusion and multi-level governance. Bonn: German Development Institute. 